\title{
Intraperitoneal Alpha-Lipoic Acid to prevent neural damage after crush injury to the rat sciatic nerve
} Mehmet Senoglu*1, Vedat Nacitarhan ${ }^{2}$, Ergul Belge Kurutas ${ }^{3}$,
Nimet Senoglu$^{4}$, Idris Altun ${ }^{1}$, Yalcin Atli ${ }^{3}$ and Davut Ozbag 5

Address: ${ }^{1}$ Department of Neurosurgery, Kahramanmaras Sutcu Imam University Faculty of Medicine, Kahramanmaras, Turkey, ${ }^{2}$ Department of Physical Medicine and Rehabilitation, Kahramanmaras Sutcu Imam University Faculty of Medicine, Kahramanmaras, Turkey, ${ }^{3}$ Department of Biochemistry, Kahramanmaras Sutcu Imam University Faculty of Medicine, Kahramanmaras, Turkey, ${ }^{4}$ Department of Anaesthesiology and Reanimation, Kahramanmaras Sutcu Imam University Faculty of Medicine, Kahramanmaras, Turkey and ${ }^{5}$ Department of Anatomy, Kahramanmaras Sutcu Imam University Faculty of Medicine, Kahramanmaras, Turkey

Email: Mehmet Senoglu* - mehmetsenoglu@hotmail.com; Vedat Nacitarhan - nacitarhan@ttnet.net.tr; Ergul Belge Kurutas - ekurutas@hotmail.com; Nimet Senoglu - nimetsenoglu@hotmail.com; Idris Altun - idrisaltun46@hotmail.com; Yalcin Atli - atliyalcin@gmail.com; Davut Ozbag - davutozbag@hotmail.com

* Corresponding author

\section{Published: 25 November 2009}

Journal of Brachial Plexus and Peripheral Nerve Injury 2009, 4:22 doi:10.1 186/1749-722I-4-22
Received: I September 2009

Accepted: 25 November 2009

This article is available from: http://www.jbppni.com/content/4/I/22

(c) 2009 Senoglu et al; licensee BioMed Central Ltd.

This is an Open Access article distributed under the terms of the Creative Commons Attribution License (http://creativecommons.org/licenses/by/2.0), which permits unrestricted use, distribution, and reproduction in any medium, provided the original work is properly cited.

\begin{abstract}
Objective: Crush injury to the sciatic nerve causes oxidative stress. Alfa Lipoic acid (a-LA) is a neuroprotective metabolic antioxidant. This study was designed to investigate the antioxidant effects of pretreatment with a-LA on the crush injury of rat sciatic nerve.

Methods: Forty rats were randomized into four groups. Group I and Group II received saline (2 $\mathrm{ml}$, intraperitoneally) and a-LA ( $100 \mathrm{mg} / \mathrm{kg}, 2 \mathrm{ml}$, intraperitoneally) in the groups III and IV at the 24 and I hour prior to the crush injury. In groups II, III and IV, the left sciatic nerve was exposed and compressed for 60 seconds with a jeweler's forceps. In Group I $(n=10)$, the sciatic nerve was explored but not crushed. In all groups of rats, superoxide dismutase (SOD) and catalase (CAT) activities, as well as malondialdehyde (MDA) levels were measured in samples of sciatic nerve tissue.

Results: Compared to Group I, Group II had significantly decreased tissue SOD and CAT activities and elevated MDA levels indicating crush injury $(p<0.05)$. In the a-LA treatment groups (groups III and IV), tissue CAT and SOD activities were significantly increased and MDA levels significantly decreased at the first hour $(p<0.05)$ and on the $3^{\text {rd }}$ day $(p<0.05)$. There was no significant difference between a-LA treatment groups $(p>0.05)$.

Conclusion: A-LA administered before crush injury of the sciatic nerve showed significant protective effects against crush injury by decreasing the oxidative stress. A-LA should be considered in the treatment of peripheral nerve injuries, but further studies are needed to explain the mechanism of its neuroprotective effects.
\end{abstract}




\section{Introduction}

The rat sciatic nerve is a well-established preparation for studying peripheral nerve injuries. Focal crush injury causes axonal interruption but preserves the connective sheaths (axonotmesis). As regards this type of injury, nerve regeneration is usually successful [1].

The increased formation of reactive oxygen species (ROS) and decreased antioxidant defense is defined as oxidative stress, which is widely recognized as an important feature of many diseases. Superoxide dismutase (SOD), and catalase (CAT) are cellular antioxidants, which protect cells from oxidative stress. Lipid peroxidation (LPO) is one of the most important expressions of oxidative stress induced by ROS. Malondialdehyde (MDA) is an indicator of lipid peroxidation, and increases in various diseases [2].

Alpha-Lipoic acid (a-LA) is a powerful lipophilic antioxidant in vitro and in vivo, which plays a pivotal role as cofactor in many mitochondrial reactions, readily absorbed from the diet and can easily cross the blood brain barrier [3].

It is known to act as scavenger of many reactive oxygen species and to interact with other antioxidants such vitamin $\mathrm{C}$ and vitamin $\mathrm{E}$, resulting in their regeneration. Due to its antioxidant activity, a-LA has been proposed as a treatment for oxidative disorders of the nervous system that involve free radicals since it exerts a profound neuroprotective effect in experimental models of stroke, trauma, degenerative disorders of the CNS and diabetes [3].

Administration of a-LA to rodents has been demonstrated to reduce the damage that occurs after ischemia-reperfusion injuries in the cerebral cortex [3], heart $[4,5]$ and peripheral nerve [6], and after injection of NMDA into the striatum [7]. However, to our knowledge, the effects of aLA on crush injury have not been investigated in the English literature [3-7].

The increased formation of ROS and decreased antioxidant defense is defined as oxidative stress, which is widely recognized as an important feature of many diseases. SOD, and CAT are cellular antioxidants, which protect cells from oxidative stress. LPO is one of the most important expressions of oxidative stress induced by ROS. MDA is an indicator of lipid peroxidation, and increases in various diseases [2].

The purpose of this study was to investigate the effects of a-LA on sciatic nerve injury by measurement of SOD and CAT activities, as well as MDA level in sciatic nerve crush injury model in rats.

\section{Materials and methods \\ Animals and Surgery}

This prospective, experimental, sham-control study was performed in the animal laboratory of the Kahramanmaras Sutcu Imam University, Faculty of Medicine. Female Sprague-Dawley rats were obtained from Experimental Research Laboratory of Sutcu Imam University Faculty of Medicine. The experimental design was approved by the Ethics committee of KSU. Rats were fed with standard rat diet routinely, however they were deprived of food for $12 \mathrm{~h}$ prior to the first operation. All rats had free access to standard rat chow and tap water.

Forty adult female Sprague-Dawley rats (200-250 grams) were used in this study. Rats were randomly divided into four groups including one sham, one control and two treatment groups.

Group I - (Sham group) Normal adult female rats (Noncrush): Non-crush group, no intervention was made, simply sciatic nerve samples were taken.

Group II - (Control group) 60 seconds of sciatic crush was performed and then sciatic nerve samples were taken at the 1st hour.

Group III - Crush-a-LA group (1 hr): $100 \mathrm{mg} / \mathrm{kg}$ intraperitoneal a-LA injection was done 24 and 1 hour before crush injury. Sixty seconds of crush was performed. Sciatic nerve samples were taken at the 1 st hour.

Group IV - Crush-a-LA group (3rd day): $100 \mathrm{mg} / \mathrm{kg}$ intraperitoneal a-LA injection was done 24 and 1 hour before crush injury. Sixty seconds of crush was performed. Sciatic nerve samples were taken on the 3rd day.

Groups I and II received saline ( $2 \mathrm{ml}$, intraperitoneally). However, groups III and IV received saline plus a-LA (100 $\mathrm{mg} / \mathrm{kg}, 2 \mathrm{ml}$, intraperitoneally [MEDA Pharma GmbH \& Co. KG]) [8] at $1 \mathrm{~h}$ and $24 \mathrm{~h}$ before the crush injury. We aimed to investigate the early effects of antioxidant therapy with a-LA. In Group I, sciatic nerve was explorated but not crushed. Sciatic nerve injury was induced in groups II, III and IV. Briefly stated, exploration was conducted under anesthesia with intraperitoneal pentobarbital $(50 \mathrm{mg} / \mathrm{kg})$, while body temperature was maintained by using a heating blanket at $35-37^{\circ} \mathrm{C}$. The sciatic nerve was exposed in the mid-gluteal region through biceps muscle dissection under an operating microscope, crushed by a \#4 Jeweler's forceps at the mid-point for 60 seconds, then unclamped. The site of crush was marked with a 5-0 suture tied in surrounding muscle. The operated animals were allowed and survived. The nerves were re-exposed under the operating microscope one hour later in groups I, II and III, and 3 
days later in Group IV and the nerve tissue was harvested. One-centimeter-long sciatic nerve segments centered on the lesion site points were collected for biochemical analyses. No prophylactic antibiotics were given. The experimental model was very well tolerated. No animal died during the operations.

\section{Preparation of tissue homogenates}

Tissue samples were immediately excised, weighed, perfused with $1.15 \%$ ice-cold $\mathrm{KCl}$, minced, then homogenized in five volumes $(\mathrm{w} / \mathrm{v})$ of the same solution, using a Heidolph 50110 R2R0 homogenizer. Antioxidant enzymes and MDA assays were performed on the supernatant preparation in a Sorvall RC-2B centrifugation of the homogenate at $14.000 \mathrm{rpm}$ for $30 \mathrm{~min}$ at $+4{ }^{\circ} \mathrm{C}$.

\section{Evaluation of biochemical parameters}

CAT activities were determined by measuring the decrease in hydrogen peroxide concentration at $230 \mathrm{~nm}$ by the method of Beutler [9]. Assay medium consisted of $1 \mathrm{M}$ Tris HCl-5 mM Na${ }_{2}$ EDTA buffer solution ( $\mathrm{pH} 8.0$ ), $1.0 \mathrm{M}$ phosphate buffer solution ( $\mathrm{pH} 7.0$ ), and $10 \mathrm{mM} \mathrm{H}_{2} \mathrm{O}_{2}$. CAT activity was expressed as $\mathrm{U} / \mathrm{mg}$ protein.

SOD activity was measured according to the method described by Fridovich [10]. This method employs xanthine and xanthine oxidase to generate superoxide radicals which react with p-iodonitrotetrazolium violet (INT) to form a red formazan dye which was measured at 505 $\mathrm{nm}$. Assay medium consisted of the $0.01 \mathrm{M}$ phosphate buffer, CAPS (3-cyclohexilamino-1-propanesulfonicacid) buffer solution (50 mM CAPS, $0.94 \mathrm{mM}$ EDTA, saturated $\mathrm{NaOH})$ with $\mathrm{pH} 10.2$, solution of substrate $(0.05 \mathrm{mM}$ xanthine, $0.025 \mathrm{mM}$ INT) and $80 \mathrm{U} / \mathrm{L}$ xanthine oxidase. SOD activity was expressed as $\mathrm{U} / \mathrm{mg}$ protein.

LPO level in the tissue samples was expressed as MDA. It was measured according to procedure of Ohkawa et al [11]. The reaction mixture contained $0.1 \mathrm{ml}$ of sample, $0.2 \mathrm{ml}$ of $8.1 \%$ sodium dodecyl sulphate (SDS), $1.5 \mathrm{ml}$ of $20 \%$ acetic acid and $1.5 \mathrm{ml}$ of $0.8 \%$ aqueous solution of TBA. The mixture $\mathrm{pH}$ was adjusted to 3.5 and volume was finally made up to $4.0 \mathrm{ml}$ with distilled water and $5.0 \mathrm{ml}$ of the mixture of n-butanol and pyridine $(15: 1, v / v)$ were added. The mixture was shaken vigorously. After centrifugation at $4000 \mathrm{rpm}$ for $10 \mathrm{~min}$, the absorbance of the organic layer was measured at $532 \mathrm{~nm}$. The results of MDA were expressed as $\mathrm{nmol} / \mathrm{mg}$ protein.

\section{Assay of Protein levels}

The protein concentration of the tissue was measured in digital Spectronic-20 spectrophotometer by the method of Lowry [12].

\section{Statistical analysis}

All variables were expressed as medians, mean \pm standard deviation with the range. Data were analyzed using MannWhitney U-test. Differences were considered significant when the probability was less than 0.05. All data were entered and processed by an SPSS 9.05 for Windows statistical package.

\section{Results}

Oxidative parameter results are presented in Table 1. Results of the antioxidants levels in all groups are presented in Figures 1, 2, 3.

Compared with sham group (Group I), tissue SOD and CAT activities decreased and MDA level elevated significantly in the control group (Group II), which indicated crush injury $(\mathrm{p}<0.05)$. After a-LA treatment tissue SOD and CAT activities increased and MDA level decreased significantly, at the first hour (Group III, p < 0.05) and on the 3rd day (Group IV, $\mathrm{p}<0.05$ ). However, there were no significant differences between treatment groups (Groups III and IV, $\mathrm{p}>0.05$ ).

\section{Discussion}

In the present study, we investigated antioxidant effects of a-LA on sciatic nerve which was subjected to 60 seconds of crush injury, based on differences observed in biochemical parameters measured. We observed that a-LA had antioxidant effects on injured sciatic nerve and these effects were similar at the first hour and on the $3^{\text {rd }}$ day.

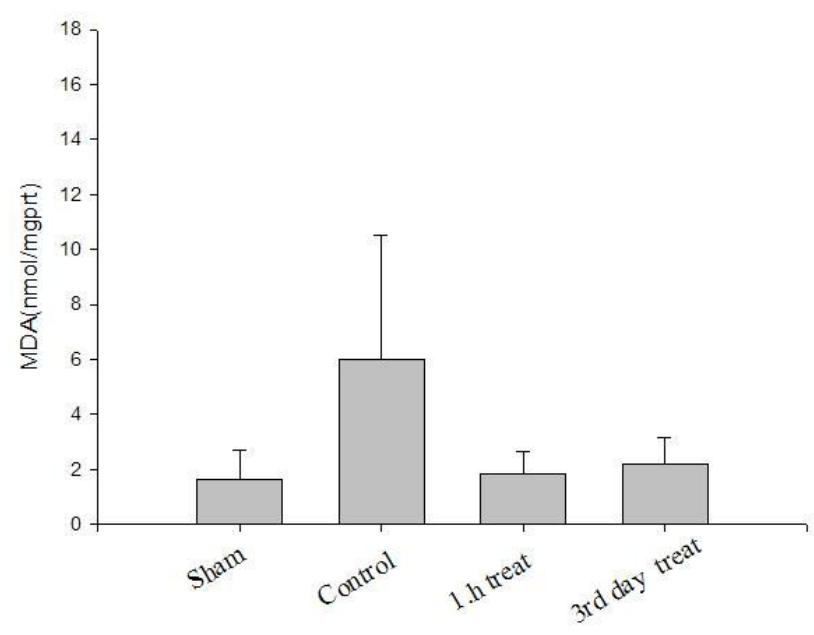

Figure I

Sciatic nerve MDA (nmol/mg protein) levels in all groups. 


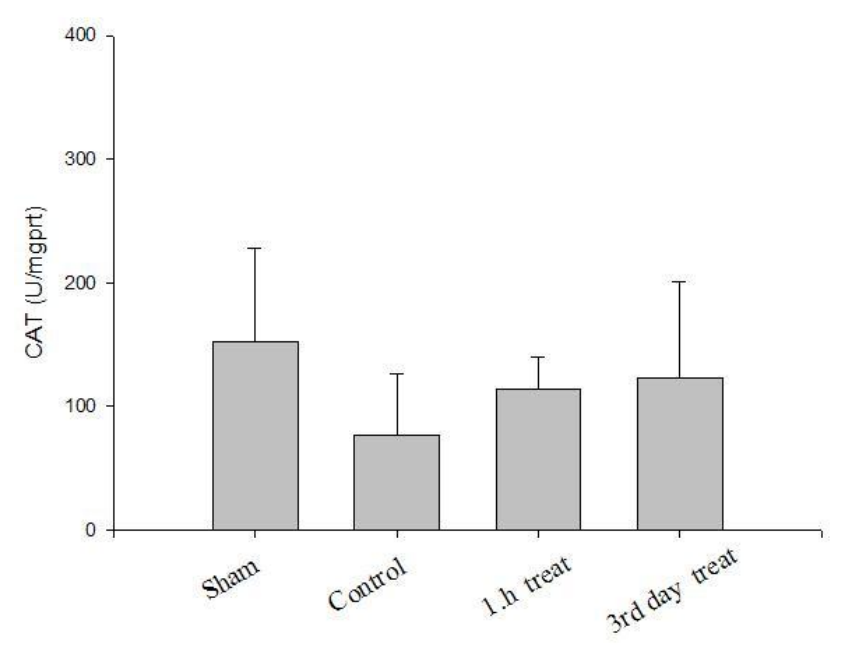

Figure 2

Sciatic nerve CAT (U/mg protein) levels in all groups.

The pathophysiology of the crush injury has not been fully understood, and it has been debated whether the ischemia, secondary to compression, or the mechanical deformation of nerve fibers per se is the more significant etiologic factor [13].

Nerve injury may depend on the length of time of crush insult. During a pilot study of our research, we showed that especially 60-second compression caused injury in

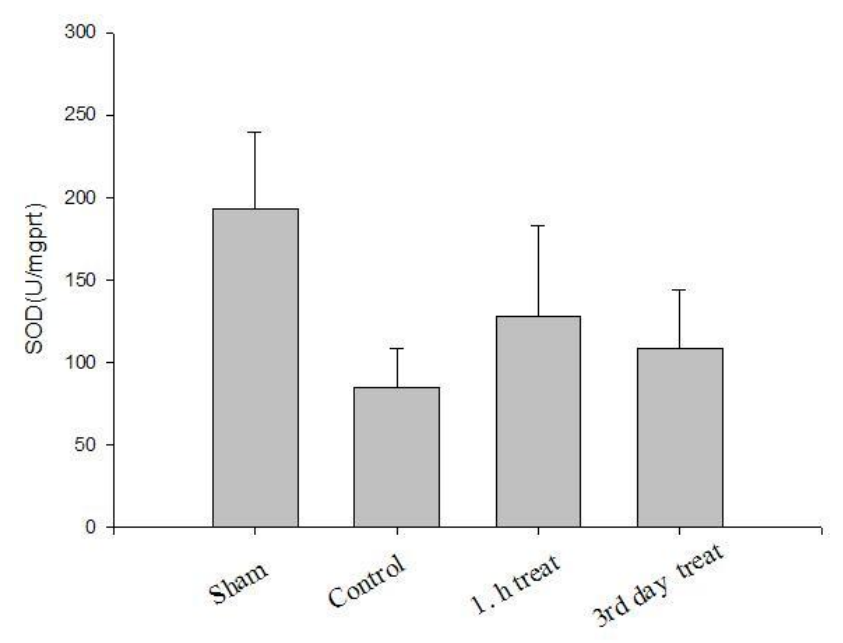

Figure 3

Sciatic nerve SOD (U/mg protein) levels in all groups. sciatic nerve. After the injury due to the tissue destruction, free oxygen radicals increase and cause tissue damage $[14,15]$.

Normal cell functions and integrity of cell structures may be broken via considerable reactivity of ROS. The organism has enzymatic (e.g. superoxide dismutase, catalase, glutathione peroxidase) and non-enzymatic (e.g. vitamin C, vitamin E) antioxidant mechanisms that work as scavengers for the harmful ROS. Radical-scavenging antioxidants are consumed by the increased free radical activity. Oxidative stress can be defined as an increase in oxidants and/or a decrease in antioxidant capacity. Although determination of either oxidants or antioxidant components alone may give information about the oxidative stress, determination of oxidants along with antioxidants is more useful in this context. Therefore, oxidants and antioxidant capacity should be measured simultaneously to assess oxidative stress more accurately. In addition, the total plasma LPO level, as an indicator of oxidative stress, reflects the redox balance between oxidation and anti-oxidation. In addition, excess amounts of ROS generated in inflamed tissues can cause injury to host cells and also induce DNA damage and mutations [16]. And, oxidative DNA damage has been suggested to play an important role in the development of cancer [17]. In several studies, increase in oxidative components or decrease in antioxidants or both have been reported in subjects with either acute or chronic various diseases [18-21].

Antioxidant activity is a relative concept: it depends on the kind of oxidative stress and the kind of oxidizable substrate (e.g., DNA, lipid, protein). To control oxidative processes, biological systems have been equipped with several antioxidant mechanisms. Antioxidant enzymes such as SOD and CAT are concerned with the removal of superoxide anion and peroxide. An imbalance between oxidative and antioxidative processes results in oxidative stress. Drugs can intervene in oxidative processes as antioxidants and delay or prevent their damaging effects. A-LA acid is an example of an existing drug therapeutic effect of which has been related to its antioxidant activity. Many experimental results show that both lipoic acid and Dihydrolipoic acid (DHLA) can improve the antioxidant capacity of tissue against different forms of oxidative stress. Hence, some physicians started to administer lipoic acid to patients with liver cirrhosis, mushroom poisoning, heavy metal intoxication and diabetic polyneuropathy [22].

The SOD-CAT system provides the first defense against oxygen toxicity. SOD catalyzes the dismutation of the superoxide anion radical to water and hydrogen peroxide, which is detoxified by the CAT activity. Usually a simultaneous induction response in the activities of SOD and 
Table I: The activities of antioxidant enzymes and MDA levels in four groups.

\begin{tabular}{|c|c|c|c|c|c|c|}
\hline & \multicolumn{2}{|c|}{ MDA (nmol/mg prt) } & \multicolumn{2}{|c|}{ CAT (U/mg prt) } & \multicolumn{2}{|c|}{ SOD (U/mg prt) } \\
\hline & Mean \pm SD & $\underset{(\min -\max )}{\text { Median }}$ & Mean \pm SD & $\begin{array}{c}\text { Median } \\
(\text { min-max })\end{array}$ & Mean \pm SD & $\begin{array}{c}\text { Median } \\
(\text { min-max })\end{array}$ \\
\hline $\begin{array}{l}\text { Group I } \\
\text { (sham) }\end{array}$ & $1.64 \pm 1.05$ & $\begin{array}{c}1.49 \\
(0.48-3.90)\end{array}$ & $152.18 \pm 75.29$ & $\begin{array}{c}150.30 \\
(55.27-339.72)\end{array}$ & $193.21 \pm 46.38$ & $\begin{array}{c}194.60 \\
(111.06-276.40)\end{array}$ \\
\hline $\begin{array}{l}\text { Group II } \\
\text { (control) }\end{array}$ & $6.02 \pm 4.50$ & $\begin{array}{c}4,10 \\
(3.25-16.80)\end{array}$ & $76.43 \pm 50.43$ & $\begin{array}{c}64.57 \\
(24.38-157.75)\end{array}$ & $84.58 \pm 23.83$ & $\begin{array}{c}79,00 \\
(50.86-121.96)\end{array}$ \\
\hline $\begin{array}{c}\text { Group III } \\
\text { Crush-a-LA group (I hr) }\end{array}$ & $1.84 \pm 0.83$ & $\begin{array}{c}1,90 \\
(0.25-3.39)\end{array}$ & $114.14 \pm 25.99$ & $\begin{array}{c}\mid 12.81 \\
(73.49-151.86)\end{array}$ & $128.12 \pm 54.60$ & $\begin{array}{c}125.82 \\
(70.45-217.56)\end{array}$ \\
\hline $\begin{array}{c}\text { Group IV } \\
\text { Crush-a-LA group } \\
\text { (3rd day) }\end{array}$ & $2.18 \pm 0.98$ & $\begin{array}{c}2.12 \\
(0.60-3.90)\end{array}$ & $122.89 \pm 77.63$ & $\begin{array}{c}98.82 \\
(76.21-339.72)\end{array}$ & $108.21 \pm 35.56$ & $\begin{array}{c}103.93 \\
(54.40-172.01)\end{array}$ \\
\hline
\end{tabular}

Values were expressed as mean \pm SD and median and range. Group I (Control), Group II (Sham), Group III and IV (Treatment).

CAT is observed when an exogen antioxidant is applied [23]. In the present study, the activities of SOD and CAT were also found to be high in sciatic tissue of rats in groups III and IV. The activity of SOD was reported to be higher in various diseases by several workers $[19,21]$ indicating high production of superoxide anion radical. Since CAT levels were detected high in sciatic tissue of rats in groups III and IV, this may be attributed to high production of peroxide radicals. Increased SOD and CAT activities in in those groups may be a response against oxidative stress.

The extent of LPO is determined by the balance between the production of oxidants and the removal and scavenging of those oxidants by antioxidants. Therefore, lipid peroxidation has been extensively used as a marker of oxidative stress [24]. Antioxidants are potential candidates for prevention or treatment of oxidative damage and free radical injury $[5,25]$.

In this study, tissue MDA levels increased and CAT and SOD activities decreased significantly in the control group compared with sham group showing crush injury. After aLA treatment, groups III and IV had significantly higher tissue SOD and CAT activities and lower MDA levels than control group showing antioxidative effects. However, these antioxidant effects were similar in treatment groups (groups III and IV) showing that preventive antioxidant effects of a-LA took place in the early phase. This finding was concordant with the finding of decreased oxidative injury (i.e. decreased MDA levels in nerve tissue) seen in pretreated groups, which was confirmed by biochemical parameters. Oxidative stress is a mechanism of nerve injury but likely not the major mechanism, and that therapeutic strategy for neuroprotection from crush injury should not be based on antioxidants alone.
Further clinical and laboratory investigations focusing on specific mechanism of antioxidant effects of a-LA, and its therapeutic effects in peripheral nerve injury is warranted.

\section{Abbreviations}

SOD: superoxide dismutase; CAT: catalase; MDA: malondialdehyde; a-LA: Alfa Lipoic acid; CNS: Central Nervous System; ROS: reactive oxygen species; LPO: Lipid peroxidation; DHLA: Dihydrolipoic acid.

\section{Competing interests}

The authors declare that they have no competing interests.

\section{Authors' contributions}

MS and NS designed the study and drafted the manuscript. MS and IA performed experimental operations. EBK, YA and DO had specimen collection of this experimental study. VN and performed the statistical analysis. All authors read and approved the final manuscript.

\section{References}

I. Gao S, Fei M, Cheng C, Yu X, Chen M, Shi S, Qin J, Guo Z, Shen A: Spatiotemporal Expression of PSD-95 and nNOS After Rat Sciatic Nerve Injury. Neurochem Res 2008, 33(6): 1090-100.

2. Koracevic D, Koracevic G, Djordjevic V, Andrejevic S, Cosic V: Method for the measurement of antioxidant activity in human fluids. J Clin Pathol 200I, 54:356-6I.

3. Packer L, Tritschler HJ, Wessel K: Neuroprotection by the metabolic antioxidant alpha-lipoic acid. Free Radic Biol Med 1997, 22:359-78.

4. Schonheit K, Gille L, Nohl H: Effect of alpha-lipoic acid and dihydrolipoic acid on ischemia/reperfusion injury of the heart and heart mitochondria. Biochimica et Biophysica Acta 1995, I 27 1:335-42.

5. Freisleben HJ: Lipoic acid reduces ischemia-reperfusion injury in animal models. Toxicology 2000, I48: I59-7I.

6. Mitsui Y, Schmelzer JD, Zollman PJ, Mitsui M, Tritschler HJ, Low PA: Alpha-lipoic acid provides neuroprotection from ischemiareperfusion injury of peripheral nerve. Journal of Neurological Sciences 1999, 163:1 1-6.

7. Greenamyre JT, Garcia Osuna M, Greene JG: The endogenous cofactors, thioctic acid and dihydrolipoic acid, are neuropro- 
tective against NMDA and malonic acid lesions of striatum. Neuroscience Letters 1994, 17 I:17-20.

8. Chidlow G, Schmidt KG, Wood JPM, Melena J, Osborne NN: Alipoic acid protects the retina against ischemia-reperfusion. Neuropharmacology 2002, 43: 1015-1025.

9. Beutler E: Red Cell Metabolism. A manual of biochemical methods. 2nd edition. Grune and Stratton Inc., New York; 1984.

10. Fridovich I: Superoxide dismutase. Adv Enzymol 1974, 41:35-97.

II. Ohkawa H, Ohishi N, Tagi K: Assay for lipid peroxides in animal tissues by thiobarbituric acid reaction. Anal Biochem 1979, 95:35I-8.

12. Lowry OH, Rosebrough NJ, Farr AL, Randall RJ: Protein measurement with the folin phenol reagent. J Biochem Chem 195I, 19:265-75.

13. Powell HC, Myers RR: Pathology of experimental nerve compression. Lab Invest 1986, 55:91-100.

14. Bagdatoglu C, Saray A, Surucu HS, Ozturk H, Tamer L: Effect of trapidil in ischemia/reperfusion injury of peripheral nerves. Neurosurgery 2002, $5 \mathrm{I}: 2 \mathrm{I} 2-20$.

15. Arslan E, Milcan A, Unal S, Demirkan F, Polat A, Bagdatoglu O, Aksoy $A$, Polat G: The effects of carnitine on distally-burned dorsal skin flap: an experimental study in rats. Burns 2003, 29:22I-7.

16. Stevens RG, Nerishi K: Iron and oxidative damage in human cancer. In Biological consequences of oxidative stress: implications for cardiovascular disease and carcinogenesis Edited by: Spartz L, Bloom AD. New York: Oxford University Press; 1992:138-161.

17. Trush MA, Kensler TW: An overview of the relationship between oxidative stress and chemical carcinogenesis. Free Radic Biol Med I99I, I0:20I-9.

18. Liu LN, Mei QB, Liu L, Zhang F, Liu ZG, Wang ZP, Wang RT: Protective effects of Rheum tanguticum polysaccharide against hydrogen peroxide-induced intestinal epithelial cell injury. World J Gastroenterol 2005, I I (1 0): I 503-07.

19. Chandra M, Chandra N, Agrawal R, Kumar A, Ghatak A, Pandey VC: The free radical system in ischemic heart disease. Int J Cardiol 1994, 43: $121-5$.

20. Babbs CF: Oxygen radicals in ulcerative colitis. Free Radic Biol Med 1992, I3(2):169-8I.

21. Ezberci F, Bulbuloglu E, Ciragil P, Gul M, Belge Kurutas E, Bozkurt S, Kale IT: Intraperitoneal tenoxicam to prevent abdominal adhesion formation in a rat peritonitis model. Surg Today 2006, 36:36I-6.

22. Biewenga GP, Haenen GR, Bast A: The Pharmacology of the Antioxidant Lipoic Acid. Gen Pharmac 1997, 29(3):315-3I.

23. Cetinkaya A, Bulbuloglu E, Kantarceken B, Ciralik H, Belge Kurutas E, Buyukbese MA, Gumusalan Y: Effects of L-carnitine on oxidant/ antioxidant status in acetic acid-induced colitis. Dig Dis Sci 2006, 5 I:488-94.

24. Gutteridge JMC: Lipid peroxidation and antioxidants as biomarkers of tissue damage. Clin Chem 1995, 4I:1819-28.

25. Sherki G, Melamed Y, Offen ED: Oxidative stress induced-neurodegenerative diseases: the need for antioxidants that penetrate the blood brain barrier. Neuropharmacology 2001, 40:959-75.
Publish with Biomed Central and every scientist can read your work free of charge

"BioMed Central will be the most significant development for disseminating the results of biomedical research in our lifetime. "

Sir Paul Nurse, Cancer Research UK

Your research papers will be:

- available free of charge to the entire biomedical community

- peer reviewed and published immediately upon acceptance

- cited in PubMed and archived on PubMed Central

- yours - you keep the copyright

Submit your manuscript here:

http://www.biomedcentral.com/info/publishing_adv.asp
BioMedcentral 